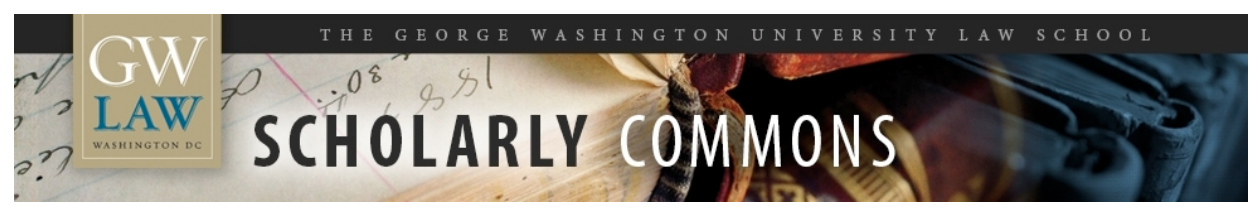

\title{
Hiring Law Professors: Breaking the Back of an American Plutocratic Oligarchy
}

Daniel I. Gordon

George Washington University Law School, dgordon@law.gwu.edu

Follow this and additional works at: https://scholarship.law.gwu.edu/faculty_publications

Part of the Government Contracts Commons

\section{Recommended Citation}

Daniel Gordon, Hiring Law Professors: Breaking the Back of an American Plutocratic Oligarchy, 19 Widener L.J. 137 (2009).

This Article is brought to you for free and open access by the Faculty Scholarship at Scholarly Commons. It has been accepted for inclusion in GW Law Faculty Publications \& Other Works by an authorized administrator of Scholarly Commons. For more information, please contact spagel@law.gwu.edu. 
HIRING LAW PROFESSORS: BREAKING THE BACK OF AN AMERICAN

\title{
PLUTOCRATIC OLIGARCHY
}

\author{
By Daniel Gordon*
}

I. Introduction: A Tale of Satire and Institutional Weaknesses

In late October or the beginning of November, a ritual is sponsored by the Association of American Law Schools ("AALS"), when the Faculty Recruitment Conference occurs on a Thursday, Friday, and Saturday at a Washington, D.C. hotel. ${ }^{1}$ Many hundreds of applicants interview at the conference, ${ }^{2}$ to which law schools send teams of faculty interviewers. The slang name for the conference is the "meat market."3

\footnotetext{
* $\quad$ Professor of Law, St. Thomas University School of Law, Miami, FL; BA
} Haverford College; J.D. Boston College. The author is grateful to Dean Alfredo Garcia and Professor Karl Gruben for their feedback. The author also is grateful to Katie Brown and Mariela Torres for their assistance. The author dedicates this piece to the best professor he has had, Robin L. Gordon, his wife, who taught him the love of shared equality.

1 See e.g., Association of American Law Schools Faculty Recruitment Conference, November 6-8, 2008, Washington, D.C. <www.aals.org/frc/>

2 The 2008 Faculty Appointments Registers through September, 2008 listed 810 applicants for law school teaching positions.

3 Brad Wendel, The Big Rock Candy Mountain: How to Get a Job in Law Teaching at "Q: Logistically Speaking, how does the hiring process work? www.lawschool.cornell.edu/faculty-pages/wendel/teaching.htm 
The process of application interviewing and hiring is a highly stylized one. ${ }^{4}$ This highly stylized interviewing and hiring process has become the subject of "how to" instructions for law teaching applicants, ${ }^{5}$ a humorous description of the what some applicants consider a long and arduous job seeking process, ${ }^{6}$ and satire about the absurdity of the hiring process from the viewpoint of an applicant. ${ }^{7}$ As much as applicants bemoan the perceived selectivity and stylization of the law professor hiring process, success rates for applicants remain relatively positive as an average of $12 \%$ of AALS registrants obtained

4 See Don Zillman, Marina Angel, Jan Laitos, George Pring, and Joseph Tomain, Uncloaking Law School Hiring: A Recruit's Guide to the AALS Faculty Recruitment Conference, 38 J. LEGAL EDUC. 345 (1988).

5 See e.g., Jeffrey M. Lipshaw, Memo to Lawyers: How Not To "Retire and Teach", 30 N.C. CEnT. L. REV. 151 (2008), Mark E. Wojcik, Survive and Thrive in Academia, 13

Chi. Bar Assoc. Rec. 36 (1999), and Paul M. Secunda, Tales of a Law Professor Lateral Nothing, 39 U. MEM. L. REV. 125 (2008).

6 David W. Case, The Pedagogical Don Quixote de la Mississippi, 33 U. MEM. L. REV. 529 (2003).

7 Kevin H. Smith, How to Become a Law Professor Without Really Trying: A Critical, Heuristic, Deconstructionist, and Hermeneutical Exploration of Avoiding the Drudgery Associated with Actually Working As an Attorney, 47 KAN. L. REV. 139 (1998). 
a law teaching position between $1991-92$ and $2004-5,{ }^{8}$ while during $2006-7$ over $13 \%$ of registrants were hired by law schools. ${ }^{9}$

Faculty candidates satirize or mock the law school faculty hiring process as overly burdensome and over stylized. However, the faculty hiring process has critical ramifications for future law teaching, legal scholarship, and law student practice success ${ }^{10}$ in addition to enhancing racial and ethnic diversity in legal education. ${ }^{11}$ Sadly, the current system of hiring law professors not only upends the lives of faculty candidates but diminishes the role of legal education as the training venue for equal rights in the American legal culture. Ultimately, law students and the legal system will suffer from the current system of hiring. This article examines the characteristics of law professors and the poor personnel hiring practices that result from the AALS faculty recruitment

8 Table 13A (2005-6) Last Fourteen Years: Success Rates of FAR Candidates in Statistical Report on Law School Faculty and Candidates for Law School Positions <www.aals.org/statistics/0506/0506_T13A_E_14yr_7yr.html> 9 2006-2007 AALS Statistical Report on Law Faculty, Association of American Law Schools Statistical Report on Law School Faculty and Candidates for Law Faculty Positions. <www.aals.org/statistics/0607/FAR-spss/success_rates.html> 10 See George C. Christie, Legal Education in An Era of Change: The Recruitment of Law Faculty, 1987 DUKE L. J. 306.

11 See Veryl Victoria Miles, Recruiting and Retaining Faculty of Color in the Legal Academy: A Longstanding Commitment of the Association of American Law Schools, 10 WASH \& LEE R.E.A.L. J. 65 (2004). 
process. $^{12}$ The article also focuses on the negative implications for faculty productivity and stability by utilizing as an example of the hiring process the experiences of one law school. ${ }^{13}$ Next, the article investigates the broader legal culture implications of the plutocratic oligarchy reinforced by the AALS faculty hiring system. ${ }^{14}$ Last, the article suggests some alternative methods of law school faculty hiring that rationalize hiring and break the oligarchic hold over of the American legal academy. ${ }^{15}$

\section{The Characteristics of Law Professors}

The law school faculty hiring process should possess as its goal the recruitment of law teachers with specific skills, competencies and personal character traits. Law professors must be highly competent in performing all the tasks assigned to them. ${ }^{16}$ They must devote substantially full time to their law school duties. ${ }^{17}$ Law professors must be

12 See notes 16 to 48 infra and accompanying text.

13 See notes 49 to 54 infra and accompanying text.

$14 \quad$ See notes 55 to 74 infra and accompanying text.

15 See notes 75 to 85 infra and accompanying text.

16 Association of American Law Schools, Bylaws and Executive Regulations Pertaining to the Requirement of Membership Sec. 6-4(a) and 2008 - 2009 ABA Standards for Approval of Law Schools, Standard 401(a).

17 Association of American Law Schools Bylaws and Executive Regulations Pertaining to the Requirements of Membership Sec. 6-4(a). 
effective teachers ${ }^{18}$ able to prepare their students for admission to the bar and effective and responsible participation in the legal profession. ${ }^{19}$ They must maintain academic rigor. ${ }^{20}$ Law teachers must be able to teach their students to participate effectively and responsibly in the legal profession in addition to legal analysis and reasoning, legal research, problem solving, and oral communication. ${ }^{21}$ Law faculty must build ready professional relationships with students ${ }^{22}$ providing student consultation and academic advising. ${ }^{23}$

Law school faculty also must demonstrate scholarly interests and performance ${ }^{24}$ and that they are capable of continuous and energetic study of new developments in areas of scholarship and teaching interests. ${ }^{25}$ As a result, all faculty must keep abreast of developments in their teaching and scholarship specialties while maintaining integrity in

18 Id. at Sec. 6-4(c) (i).

192008 - 2009 ABA Standards for Approval of Law Schools Standard 301(a).

$20 \quad$ Id. at Interpretation 301-3.

$21 \quad$ Id. at Standard 302.

22 Association of American Law Schools Bylaws and Executive Regulations Pertaining to the Requirements of Membership Sec. 6-4(a).

232008 - 2009 ABA Standards for Approval of Law Schools Standard 404(a) (1).

$24 \quad$ Association of American Law Schools Bylaws and Executive Regulations Pertaining to the Requirements of Membership Sec. 6-4(c) (iii).

25 Id. at Sec. 6-6(b). 
the conduct of scholarship. ${ }^{26}$ In addition to producing scholarship, law professors serve the law school community. ${ }^{27}$ A faculty member must be able to formulate and administer a variety of law school policies and components including curriculum, methods of instruction, admissions, academic standards, and personnel questions involving faculty recruitment, retention, promotion, and tenure. ${ }^{28}$ Faculty members must be able to participate in institutional self reflection evaluating the strengths and weaknesses of their law schools. ${ }^{29}$ An ability to participate in strategic planning also remains important. ${ }^{30}$

Overall, faculty retains primary responsibility for determining law school institutional policy. ${ }^{31}$ Beyond the law school, law professors possess obligations to the university community where a law school remains sponsored by a university ${ }^{32}$ and to the legal profession. ${ }^{33}$ In addition, law professors must demonstrate on behalf of their law school a commitment to equality of opportunity in legal education without regard to race,

262008 - 2009 ABA Standards for Approval of Law Schools Standard 404(a) (4).

$27 \quad$ Id. at Standard 404(a).

$28 \quad$ Id. at Standard 205(b).

29 Id. at Standard 202.

$30 \quad$ Id. at Standard 203.

31 Association of American Law Schools Bylaws and Executive Regulations Pertaining to the Requirements of Membership Sec. 6-5(a).

322008 - 2009 ABA Standards for Approval of Law Schools Standard 404(a) (3).

33 Id. at Standard 404(a) (5). 
color, religion, national origin, gender, sexual orientation, age and disability ${ }^{34}$ in addition to the ability to actively provide opportunities for the study of law to underrepresented groups. $^{35}$

In order to perform all of her various tasks, a law professor must be able to participate responsibly in group deliberative processes of a law faculty ${ }^{36}$ in addition to creating an atmosphere in which faculty and students voice opinions and exchange ideas. $^{37}$ Equally important, a law professor must be able to share responsibilities not only with faculty colleagues but also with a dean. ${ }^{38}$

\section{The Hiring Process: Poor Institutional Management Practices}

Law school professors must possess not only substantive legal knowledge but dozens of other scholarly, administrative, and interpersonal capabilities. The law school hiring process functions to assure the hiring of well rounded individuals. The AALS faculty recruitment process begins with the Faculty Appointments Register in which candidates provide background information including legal education, graduate legal education, teaching experience, courses desired to be taught, scholarship, employment

$34 \quad$ Id. at Standard 211(a).

$35 \quad$ Id. at Standard 212(a).

36 Association of American Law School Bylaws and Executive Regulations Pertaining to the Requirements of Membership Sec. 6-4(c) (iv).

372008 - 2009 ABA Standards for Approval of Law Schools Standard 404(a) (1). $38 \quad$ Id. at $205(\mathrm{~b})$. 
history, and references. These data for each candidate arrive at the law schools in three batches during the late summer and early fall. Each candidate's data arrives as one page among hundreds of pages for hundreds of applicants. ${ }^{39}$ During late Summer and Fall, 2008, law schools received three distributions of Faculty Appointments Register lists with eight hundred ten forms from applicants. ${ }^{40}$

The eight hundred ten forms typically are circulated to law faculty for their reviews. Often, a Faculty Recruitment Committee reviews the forms. ${ }^{41}$ Utilizing a generic law school with a tenured and tenure track faculty of twenty five faculty members, it is possible to track the AALS based hiring process. The author's law school

39 Association of American Law Schools, Services, Faculty Appointment Register $<$ www.als.org/frs/far.php $>$ (As appears on January 15, 2009).

40 Distribution 1 on August 18, 2008 included 592 Forms while Distribution 2 on September 8, 2008 included 108 Forms and Distribution 3 on September 29, 2008 included 110 Forms. There was a Distribution 4 on February 4, 2009 with 65 Forms, but the February distribution played no role in the interviewing process for the November 68, 2008 Faculty Recruitment Conference in Washington, D.C.

41 See Kevin H. Smith, note 7 supra, at 155 and Don Zillman, Marina Angel, Jan Laitos, George Pring, and Joseph Tomain, note 4 supra, at 347. 
has about twenty five tenured and tenure track faculty, ${ }^{42}$ and provides a model for the generic law school. The 2008-9 faculty recruitment committee consisted of five tenured and tenure track faculty members. ${ }^{43}$ No doubt at many law schools, only members of the recruitment committee review the eight hundred ten AALS forms. At St. Thomas, all members of the recruitment committee review all of the AALS register forms. In addition, at St. Thomas, the forms were circulated to all twenty-five tenured and tenure track faculty for review. An alternative would be to have each member of the faculty recruitment committee review an assigned portion of the eight hundred ten forms.

All members of the faculty or, at many schools, all members of the recruitment committee submit their preferences and a vote tally is kept for the selections. Candidates with the most faculty or committee votes are contacted by phone, or if need be, by e-mail with an invitation to interview with a faculty recruitment subcommittee of three members at the AALS recruitment conference in Washington. Typically for St. Thomas, the Committee interviews between twenty two and thirty applicants.

42 St. Thomas University School of Law in Miami, Florida. The $2007-8$ AALS Directory of Law Teachers lists forty four employees but that list includes non-tenured and tenure track visiting professors, writing professors, and administrators.

43 Professors Carol Zeiner, Karl Gruben, Lenora Ledwon, Lydie Pierre-Louis, and Daniel Gordon. Dean Alfredo Garcia served in an ex-officio capacity. 
The subcommittee chooses between three and five Washington interviewees for on-campus, one day interviews including "a job talk" scholarship presentation at a luncheon attended by most faculty. ${ }^{44}$ In addition to the job talk luncheon, the candidate visits with groups of faculty in one hour components in the faculty lounge where the candidate is peppered with questions about teaching preferences, scholarship aspirations, and sundry other legal education and legal issues. Time is also allocated for meetings with the University president, the Dean and Associate Dean for Academics, the library staff for a library and campus tour, and students recruited by the law review or student bar association. Some faculty wait until dinner to interview the candidate. Sometimes, a courteous faculty member remembers to offer the candidate a restroom break.

References listed on the AALS register form are called.

Shortly after the last candidate leaves campus, the faculty meets to decide who to recommend to the dean for hiring. The discussions and comments are wide ranging, but at St. Thomas emphasis is placed on the job talk and specific insights from individual members of the faculty who met or ate with the candidate. A candidate who bored the faculty at the job talk luncheon faces questions about whether the candidate will connect with the students in the classroom. Inconsistencies in discussions about teaching preferences have caused concern in faculty deliberations. Finally, a vote is taken and the job of hiring shifts to the Dean who negotiates with candidates. Then, the faculty waits as the burden of choice shifts to a candidate with an offer of employment.

$44 \quad$ See David W. Case, note 6 supra at 561. 
The minutae of the hiring process should not obscure the law school institutional objectives of the process. Law schools must hire well rounded individuals with a variety of teaching scholarship, administrative, and collaborative skills. ${ }^{45}$ When the importance of the objective is considered the AALS faculty recruitment process transforms into a managerial absurdity. During late summer and fall, 2008, law school faculty and their faculty recruitment committees reviewed eight hundred ten forms with a variety of data included on each form. If a faculty member spent an unconscionable one minute on each form, the enterprise would take thirteen and a half hours. If a respectful three minutes is spent reviewing each form, the process would take forty and a half hours. If a generous four minutes are spent on each form, the process would take fifty four hours, more time required for classroom teaching for a three credit law school course. ${ }^{46}$ A sample of twenty-five AALS Faculty Appointments Register forms from summer and fall, 2008 shows that applicants listed 273 course preferences for the subjects they most like to teach, other subjects they may be interested in teaching, and other subjects they would be

45 See notes 16 to 39 supra, and accompanying text.

462008 - 2009 ABA Standards for Approval of Law Schools Interpretation $304-4$ which provides; "Law schools on a conventional semester typically require 700 minutes of instruction time per 'credit', exclusive of time for an examination... If a law school on a semester system offers classes in units of fifty minutes per credit, it can provide 700 minutes of instruction in 14 classes." 
willing to teach if asked spaces on the forms. ${ }^{47}$ This represents an average of almost eleven courses preferences per form. If that average held throughout all eight hundred ten forms, faculty involved with recruitment would have to hunt through around 8900 listed course preferences in order to narrow the field to candidates who meet current curricular needs. Even if a recruitment committee split reviews of forms among individual committee members, the task is daunting and time consuming.

The initial search for well rounded candidates for law teaching consumes at most a few minutes for each candidate. Even the AALS Faculty Recruitment Conference interviews can take no more than thirty minutes if interviewers talk to more than twenty or so candidates, eat lunch, take a couple of breaks, and discuss impressions of candidates. ${ }^{48}$ If a law school is very serious about seeing a large number of candidates, twenty minute interviews seem more in order. Campus visits last no more than a day, possibly in some situations a little longer. At most, few faculty spend more than an hour talking directly to a candidate and another hour listening to a job talk. Even a faculty host for a day cannot spend too much time with a candidate as other faculty colleagues must get their turn. Law schools are supposed to choose well rounded, competent, collaborative individuals who have the potential to teach qualitatively, produce quality scholarship on a regular basis, and provide a variety of services to the law school,

47 The sample was forms 393 to 418 which represented the mid point of the 810 Forms in the first three AALS Faculty Appointments Register. 48 See Jeffrey M. Lipshaw, note 5 supra, at 154. 
university, and the community. These hiring choices are made through the AALS hiring process on the basis of a one to possibly ten minute review of data forms, a thirty minute interview, and a one day visit to campus during which no one faculty member can spend more than a couple of hours assessing a candidate's skills and potential.

\section{Testing the Hiring Process: The Experience of One Law School}

The AALS hiring process challenges American law schools to choose well rounded law professors capable of quality teaching, sophisticated scholarship, and collegial service on the basis of a one to ten minute review of a candidate's biographical form, a thirty minute interview, and a one day visit to campus. Presumably, some faculty also read some already published candidate scholarly pieces. Such a system fails to cater to employment success for a number of reasons. First, the candidate review process fails to allow for any in depth observations of the candidate's teaching abilities and collegial character, specifically the ability to participate responsibly in law school faculty group deliberative processes. $^{49}$

In addition, a review of pieces published by candidates can give an idea about the quality of a candidate's scholarship abilities and a job talk can give some indication of a candidate's analytical abilities and even classroom demeanor. However, those insights are limited at best. Job talks can be highly practiced affairs, a marketing process, which

49 Association of American Law Schools Bylaws and Executive Regulations Pertaining to the Requirements of Membership Sec. 6-4(c) (iv). 
really suggests little about a candidate other than the candidate knows how to perfect one scholarship presentation. One candidate described the function of the job talk as "[c]an this person speak well enough to give him a job?" 50 Past scholarship production indicates at best that a candidate possessed the motivation to produce scholarship in the past, even the recent past but says little about the future.

Also, the time-cabined process provides little or no opportunity to determine whether a candidate possesses the strength to join faculty colleagues in challenging a Dean or a University administrator to assure that “. . . [a] law school shall maintain an educational program that prepares its students for admission to the bar, and effective and responsible participation in the legal profession." ${ }^{51}$ In addition, a short meeting with a select group of students provides little or no evidence about a candidate's willingness and ability to consult with students and participate in academic advising, never mind the ability and willingness to help create an atmosphere in which students voice opinions and exchange ideas. $^{52}$

One law school provides some insight into the success or failure of the AALS faculty recruitment process during the last seven years. St. Thomas University School of Law provides a good testing ground for the AALS hiring process, because more faculty

$50 \quad$ Kevin H. Smith, note 7 supra, at 167, n. 46.

512008 - 2009 ABA Standards for Approval of Law Schools Standard 301. $52 \quad$ Id. at Standard 404(a) (1). 
taught at the law school during 2008-2009 who were hired by alternative means to the AALS than faculty who were hired through the AALS hiring system. During 2008-2009, the tenured and tenure track had twenty-five members including one visiting faculty member who had been offered a tenure track position. Fifteen faculty members became members of the St. Thomas faculty through alternate means to the AALS hiring process while ten faculty members were recruited through the AALS recruitment system.

Great emphasis is placed in the AALS recruitment process on scholarship. ${ }^{53}$ At St. Thomas, the scholarship production for two groups remains relatively close. The AALS group since 2002 has averaged six publications per faculty while the non-AALS group has averaged slightly over five publications per faculty member. ${ }^{54}$ However, when taking into account the number of years each faculty member has been at St. Thomas which is necessary because some have been at St. Thomas for only a year while others all seven years reviewed, the results remain relatively stable. The non-AALS group published close to .86 publications per service year while the AALS group published 1.05 publications per service year. However, the publication records of both groups are not evenly distributed. Of the ten AALS recruited faculty, two published $63 \%$ of the publications, while the non-AALS group has a much more consistent publication record

$53 \quad$ See Jeffrey M. Lipshaw, note 5 supra, at $156-157$.

$54 \quad$ See generally Recent Faculty Publications updated January 9, 2009. (on file with Author) Publications include law review article, book reviews, chapters in books, scholarly on-line postings, and books. 
with five faculty publishing $67 \%$ of the publications. Eight non-AALS professor published five or more publications while four of AALS professors published five or more publications. Overall, both groups remain productive scholars, though the nonAALS group appears to produce scholarship more evenly.

For service, the non-AALS group dominated during 2008-2009 the faculty committee chairs with non-AALS faculty chairing six committees or service groups including adjunct faculty review, while the AALS group provided three chairs including the Ad Hoc Bar Passage Committee. Teaching quality is hard to gauge at St. Thomas as the student evaluations are not published. Both groups have long serving, experienced teachers.

The great distinction between the groups is an important one, longevity of service. Since 2002, eight faculty members have left St. Thomas. Two taught in an LLM program that moved to another law school and one was the Librarian who moved to another library. The Librarian was a non-AALS hire, but the rest were AALS hires who either moved onto another law school or left for other institutional reasons. The AALS hiring system added significant instability to the faculty. The non-AALS system resulted in greater stability. Another indication of that stability is the current Dean, a non-AALS hire who is the first non-acting dean chosen internally from and by the faculty. Such a result should surprise no one as the non-AALS system involved the use of visitorships, local networks, or specialized hiring processes such as dean searches. The non-AALS hiring processes allowed the institution to gain greater knowledge about and insight into the candidates. The non-AALS system rationalized hiring by allowing greater time and 
review resources to be devoted to the hiring process. The non-AALS process also avoided a broader legal education culture issue, the rise of the plutocratic oligarchy.

\section{Reinforcing the Plutocratic Oligarchy}

The AALS faculty recruitment system makes little sense as an institutional management tool. With little time resources and limited deliberative bases a law school must attempt to hire the well rounded law professor with a variety of legal knowledge, teaching, scholarship, and collaborative skills. The experience of one law school demonstrates that non-AALS alternatives to hiring through the AALS programs results in productive faculty members and faculty stability. The current AALS driven hiring system implicates even broader social issues than poor employment management techniques. The AALS hiring system reinforces the existence in legal education of a plutocratic oligarchy, a group of law professors who are the product of wealth based education, controlling the hiring of more law professors who are the product of wealth based education.

The faculty of American law schools remains dominated by graduates of a few law schools. ${ }^{55}$ Fifteen law schools during the $2007-2008$ academic year provided $52.6 \%$

55 See 2007 - 2008 AALS Statistical Report on Law Faculty, Association of American Law Schools Report on Law School Faculty and Candidates for Law Faculty Positions, Faculty with JD/LLB Degrees from AALS Affiliated Law Schools. $<$ www.aals.org/statistics/2008/schools.html>. 
of the faculty listed by the AALS member schools and fee paying schools. ${ }^{56}$ Fifteen law schools of two hundred law schools accredited by the $\mathrm{ABA}^{57}$ provided one out of every two law professors in the United States, while two law schools, Harvard and Yale provided over $20 \%$ of the law professors in the United States during 2007-2008. ${ }^{58}$ An American law teaching oligarchy exists with implications for legal education hiring practices. The graduates of a small number of American law schools must be hiring the graduates of the same small number of American law schools.

Table 1 2008-2009 Faculty Feeder Schools

\begin{tabular}{|l|c|}
\hline \multicolumn{1}{|c|}{ School } & $\begin{array}{c}\text { Percent of Law Professors } \\
\text { Supplied }\end{array}$ \\
\hline Harvard & $12.3 \%$ \\
\hline Yale & $8.3 \%$ \\
\hline Michigan & $3.9 \%$ \\
\hline Columbia & $3.8 \%$ \\
\hline Chicago & $3.6 \%$ \\
\hline NYU & $3.2 \%$ \\
\hline California Berkeley & $2.6 \%$ \\
\hline Stanford & $2.5 \%$ \\
\hline Georgetown & $2.4 \%$ \\
\hline Virginia & $2.1 \%$ \\
\hline Pennsylvania & $2.0 \%$ \\
\hline Texas & $1.6 \%$ \\
\hline Northwestern & $1.6 \%$ \\
\hline Wisconsin & $1.4 \%$ \\
\hline Duke & $1.3 \%$ \\
\hline \multicolumn{1}{|c|}{ TOTAL } & $52.6 \%$ \\
\hline
\end{tabular}

$56 \quad$ The AALS Directory of Law Teachers 2007 - 2008.

57 See American Bar Association, Section of Legal Education and Admission to the Bar website, ABA - Approval Law Schools.

58 See 2007 - 2008 AALS Statistical Report, note 55 supra. 
The AALS hiring process serves as the platform for a hiring elite of American law schools. The AALS has served a legal education elite through its programming, ${ }^{59}$ and the AALS Faculty Appointments Record and Faculty recruitment conference serves that same elite. The dominant law professor feeder schools reflects the top ranked law schools in the U.S. News and World Report law school rankings. ${ }^{60}$ An argument can be made that the domination of the law teaching culture and the faculty recruitment processes by the fifteen top law schools reflects a justifiable ranking system that in turn reflects educational quality and success. ${ }^{61}$ However, such an argument overlooks a linkage between law school rankings, faculty recruitment oligarchy and educational institutional wealth. The so called top ranked law schools and the major feeder schools for faculty recruitment serve as units of the wealthiest universities in the United States as measured by university endowments.

59 See David E. Steinberg, More of the Same: Elitism and Exclusion at the AALS Annual Meeting, 54 ME. L. REV. 251 (2002).

60 U.S. News and World Report, Best Law Schools Ranked in $2009<$ http://gradschools.usnews.rankingsandreviews.com/best-graduate-schools/top-lawschools/rankings $>$.

61 Paul L. Caron and Rafael Gely, What Law Schools Can Learn from Billy Beane and the Oakland Athletics Moneyball: The Art of Winning an Unfair Game; 82 TEX. L. REV. 1483, 1514 - 23 (2004). 
Table 2

Top Recruitment Feeder Schools, University Endowments, Rankings and U.S. News and World Report Rankings

\begin{tabular}{|l|c|c|}
\hline \multicolumn{1}{|c|}{ School } & $\begin{array}{c}\text { University Endowment } \\
\text { Ranking }^{62}\end{array}$ & $\begin{array}{c}\text { U.S. News } \\
\text { Ranking }^{63}\end{array}$ \\
\hline Harvard & 1 & 2 \\
\hline Yale & 2 & 1 \\
\hline Michigan & 6 & 9 \\
\hline Columbia & 5 & 4 \\
\hline Chicago & 10 & 6 \\
\hline NYU & 24 & 3 \\
\hline Stanford & 3 & 6 \\
\hline California Berkeley & 9 & 14 \\
\hline Georgetown & 46 & 10 \\
\hline Virginia & 16 & 8 \\
\hline Pennsylvania & 7 & 15 \\
\hline Texas & 4 & 10 \\
\hline Northwestern & 8 & 35 \\
\hline Wisconsin & 29 & 10 \\
\hline Duke & 12 & 5 \\
\hline
\end{tabular}

62 2007 NACUBO Endowment Study, All Institutions Listed by Fiscal Year 2007

Market Value of Endowment Assets with Percentage Change Between 2006 and 2007

Endowment Assets, National Association of College and University Business Officers (2008). The rankings were reworked to include only universities with law schools by deleting from the rankings of universities without law schools. The Cal. Berkeley data are based on the ranking for the University of California system listing though Cal. Berkeley has its own endowment ranked at 89 for all universities and colleges. This indicates that Cal. Berkeley has more than one endowment resource. The Texas ranking includes the University of Texas system.

63 2009 U.S. News and World Report Best Law School Rankings, note 60 supra. The US News and World Report records ties in the rankings explaining why more than one law school possesses the same ranking. 
Without Georgetown's outlier university endowment ranking, the mean average university endowment ranking for the top law school faculty recruitment feeder schools was 9.71. Including Georgetown, the mean average U.S. News and World Report ranking for the same law schools was 9.2. Excluding Georgetown, the mean average law school ranking was 8.9. Wealth plays a major role in the AALS faculty recruitment process. The best evidence of the role of wealth is the interplay of Harvard and Yale in the recruitment feeder school, law school, and university endowment rankings. Harvard has over time outplaced Yale on law school faculties by a factor of $1.48,{ }^{64}$ yet in 2009 Yale bested Harvard in the U.S. News and World Report ranking by five points. ${ }^{65}$ In 2007, Harvard bested Yale in endowments by a factor of $1.53 .{ }^{66}$ Wealth rules law school faculty recruitment. Not only are the graduates of a select few law schools recruiting the graduates of their own select group of law schools, but the products of wealth based legal education are recruiting the products of wealth based legal education to join them in the ranks of law professors. The law teaching oligarchs beget the law teaching plutocrats, or maybe it is the law teaching plutocrats beget the law teaching oligarchs.

64 See 2007 - 2008 AALS Statistical Report on Faculty, note 55 supra. 1179 Harvard graduates were recruited by law schools over time while 799 Yale graduates were recruited by law schools over time.

65 See 2009 U.S. News and World Report Best Law School Rankings, note 60 supra.

662007 NACUBO Endowment Study, note 62 supra. 
American law schools have suffered traditionally from sexism and racism with ". . . identified evidence of persistent sex bias in law faculty hiring." ${ }^{\circ 7}$ Legal education has traditionally been a white male affair. ${ }^{68}$ The AALS faculty recruitment system perpetuates a law school climate that fosters a bias subtler and more pervasive even than racism and sexism. This bias is prima facie race and sex neutral. Law school faculty recruitment reinforces a bias toward the product of wealth, and masquerades wealth based education as quality education. A student sense of hierarchy in the law school classroom and the general law school environment plays an important role in students developing their own professional images. ${ }^{69}$ The AALS faculty recruitment system perpetuates a hierarchy that emanates from wealthy environments conflating intellectualism with ample financial resources. The hierarchy of American legal education not only traditionally remained strongly gendered ${ }^{70}$ but remains strongly wealth oriented and wealth driven. Applicants for law school teaching positions who did not graduate from plutocratic oligarchical law schools that already control the faculty recruitment process face outsider status. Outsider evaluations under so-called neutral

67 Deborah Jones Merritt and Barbara Reskin, Sex Race, and Credentials: The Truth About Affirmative Action in Law Faculty Hiring, 97 COLUM. L. REV. 199, 205 (1997).

68 Nancy E. Dowd and Kenneth B. Nunn, Diversity Matters: Race, Gender, and Ethnicity in Legal Education, 15 U. FLA. J.L. PUB. POL'Y 11, 12 (2003).

69 Lani Guinier, Michelle Fine, Jane Balin, Ann Bartow, and Deborah Lee Stadiel, Becoming Gentlemen; Women's Experiences at One Ivy League Law School, 143 U. PA.

L. REV. 1, 62 - 70 (1994).

$70 \quad$ Nancy Dowd and Kenneth Nunn, note 68 supra at 42. 
and objective criteria shift and "... [q]ualifications increase; previously valued institutions, evaluators, and even grades are discounted or disbelieved.",71

The faculty recruitment process for law schools needs to be reoriented and redirected. There needs to be greater attention to the objectives of the hiring process, the recruitment of well rounded and collaborative teachers and scholars. ${ }^{72}$ Law teaching should not be the preserve of the white sons of institutional, educational wealth or the daughters and sons of institutional, educational wealth. Law professors must train their students to provide competent representation to clients ${ }^{73}$ and to act with reasonable diligence and promptness. ${ }^{74}$ Those professional commitments fail to depend on the wealth of the client or the wealth of the lawyer. The preparation of law students to assume such commitments should not depend on the wealth of the law students or the wealth of the university that sponsored the law school from which their law professors graduate. Law schools need to develop alternative means of recruiting and hiring law professors.

VI. Alternative Means of Recruitment and Hiring

Law schools need to utilize alternative faculty recruitment and hiring process that are more administratively rationale than the current AALS faculty hiring processes and

$71 \quad$ Id. at 45 .

72 See notes 16 to 39 supra and accompanying text.

73 Model Rules of Professional Conduct R.1.1.

$74 \quad$ Id. at R. 1.3 . 
that avoid the current hiring practices that reinforce the legal education plutocratic oligarchy. A number of alternatives are available for law schools to use.

\section{A. The Visitorship}

The current AALS hiring system produces bad personnel management practices by compressing the hiring process for well rounded, sophisticated professionals into a matter of minutes and hours. ${ }^{75}$ Faculties fail to assess candidates in any depth and make institutional decisions with impacts that can last many years on the basis of skimpy impressions. One way to improve data gathering for personnel decision is to hire only after a candidate has spent at least a year as a visiting faculty member. This provides tenured and tenure track faculty colleagues at least one semester to observe a candidate on day to day bases before a final hiring decision is made. The downside of visitorships for law professor candidates is the never ending job interview over time during which missteps are possible unlike the AALS hiring system during which missteps are limited to one day at most. ${ }^{76}$ However, on the positive side for the candidate, a visitorship “. . goes a long way to proving your commitment to the quest, gets you a cadre of friends in the academy, and inculcates you in the lore and folkways." 77 For the law schools, visitorships as extended interviews and observations possess little or no downsides. At most, the school must tolerate a poor prospect for one year and not on a

75 See notes 42 to 48 and accompanying text.

76 David W. Case, note 6, supra, at 563.

77 Jeffrey M. Lipshaw, note 5 supra; at 163. 
tenure track review schedule. Colleagues can visit classes and observe scholarship commitment and work ethic on a day to day basis. Such extended observation provides an antidote to the prevailing system of plutocrats hiring the products of plutocracy. Instead, a candidate's actual performance becomes the focus of the hiring process.

\section{B. Legal Research and Writing Platform}

Law schools fail to value legal research and writing instructors as part of the mainstream tenure track faculty. Research and writing fails to be taken seriously as a legal teaching status and legal writing instructors are placed lower on the law school faculty hierarchy. ${ }^{78}$ The low status of research and writing professor's implicates a gender hierarchy with men higher on the hierarchy and women lower on the hierarchy. ${ }^{79}$ This hierarchical contrivance compounds the already existing overarching hierarchy created by the law schools' plutocratic oligarchy. ${ }^{80}$ Law schools should treat legal research and writing professors like all other tenured and tenure track faculty, but the ABA has undercut such a system by allowing law schools to provide only short term

78 See David T. Richie, Who is On the Outside Looking in, and What Do They See?: Metaphors of Exclusion in Legal Education, 58 MERCER L. REV. 991, 1009 - 1013 (2007).

79 See Kathryn M. Stanchi, Who's Next, The Janitors? A Socio-Feminist Critique of the Status Hierarchy of Law Professors, 73 UMKC L. REV. 467, 476-80 (2004).

$80 \quad$ See notes 59 to 71 supra and accompanying text. 
contracts for research and writing. ${ }^{81}$ As such, law schools are making an error in not taking legal research and writing faculty seriously as an ongoing and steady source of candidates for substantive law teaching positions. Legal research and writing provides a great opportunity to view the quality of pedagogical interaction between teachers and students. Legal research and writing positions, if not accorded tenure track and tenured status, serve as a form of visitorships in which the teachers test whether legal education conforms to their professional objectives and the law schools test the teachers through ongoing classroom, scholarship, and service observations. The law schools and the candidates should expect legal research and writing professors to complete scholarships and to publish. ${ }^{82}$ Like the visitorship, the legal research and writing route to recruiting tenure and tenure track substantive law teaching faculty promises an alternative to the plutocratic oligarchy of the current AALS hiring system by basing hiring decisions on extended reviews of tangible work related performance.

\section{The Legal Professor Networking System}

The most direct way to overcome the current AALS plutocratic oligarchy is a focused, individual law school centric networking system which provides to law schools leads concerning promising teachers and scholars. Such a system would be based in the existence of active law school boards of advisors that connect the law school with the

81 See 2008-2009 ABA Standards for Approval of Law Schools Interpretation $405-9$.

82 See David T. Richie, note 78 supra, at $1014-16$. 
local legal community surrounding the law school and feeder organizations. Though the dean and faculty must retain control over matters affecting the educational programs of law schools, a law school may involve alumni, students and others in a participatory or advisory capacity. ${ }^{83}$ Judges, prominent practitioners, and alumni can provide a variety of resources on an advisory board including insight into known members of the legal community suitable for teaching and scholarship. Administratively, this serves as a more rational model than the current time and information compressed model of the AALS recruitment process as trusted community advisors have the opportunity to observe over time judicial clerks and lawyer colleagues. In addition, advisory boards provide to law schools the critical opportunity to include diverse, feminist, and minority voices through representation from minority bar associations and law professor candidate feeder organizations such as the Mexican-American Legal Defense Fund, NAACP Defense Fund, Puerto Rican Legal Defense Fund, and the Native American Rights Funds. ${ }^{84}$ The law school advisory board as a faculty recruitment tool allows the law school to meet its faculty needs in the context of Miami, Memphis, Kansas City, Albuquerque, Vermillion, Grand Forks, and Seattle and not only in the context of the ever present Cambridge, New Haven, Palo Alto, Morningside Heights, and Berkeley. Finally, the plutocratic oligarchy in American law faculties can be trimmed.

$83 \quad 2008-2009$ ABA Standards for Approval of Law Schools Standard 208.

84 Veryl Victoria Miles, note 11 supra, at 68, 70. 


\section{The Creative LL.M Affiliation}

Law schools could use as hiring resources an ongoing affiliation with a LL.M in law teaching program such as the Freedman Fellow Program at Temple University Law School where fellows are introduced to the various teaching, scholarship, and service

roles of law teachers. ${ }^{85}$ Law schools should explore affiliating on a part-time basis with such LL.M programs allowing advanced LL.M students the opportunities to teach components of courses or a whole semester at the law school on short term visitorship bases. This provides the LL.M student with the opportunity to observe a prospective law school employer while the law school obtains a longer term observation period for reviewing teaching candidates. The participating law schools could contribute to any fellowship resources expended by Temple or any other such program. Again, like a visitorship, this provides greater temporal and data resources to the hiring school for its personnel decisionmaking.

\section{Conclusion}

The current AALS faculty recruitment system remains managerially irrational, forcing law school faculties and deans to make faculty hiring decisions with compressed temporal data, and observation resources. ${ }^{86}$ Worse, the system serves to reinforce the

85 See Abraham L. Freedman Teaching Fellowship at Temple University Beasley School of Law

$<$ www.law.temple.edu/servlet/retrievepage?site=templelaw\&page=Graduate_Teach $>$. $86 \quad$ See notes 39 to 48 supra and accompanying text. 
current plutocratic oligarchy in American law school faculties by allowing the products of wealth based law schools to continue to hire the products of wealth based law schools. ${ }^{87}$ Alternatives exist to the AALS system that allow faculties and deans to take more time and make greater efforts in assessing the teaching, scholarship, service, and collaborative capabilities of faculty candidates. ${ }^{88}$ Law schools need to get away from the current hiring system in order to improve the teaching, scholarship, service, and collaborative quality of faculties. Law schools also need to hire in a fashion that overcomes the current wealth driven hierarchies encouraging students to value subtly more than the power and status of wealth and the wealthy.

Plutocratic

$87 \quad$ See notes 62 to 71 supra and accompanying text.

88 See notes 75 to 85 supra and accompanying text. 